\title{
INFLUENCE OF THE PRINTING NOZZLE DIAMETER ON TENSILE STRENGTH OF PRODUCED 3D MODELS IN FDM TECHNOLOGY
}

\author{
Wojciech Kiński ${ }^{*}$, Paweł Pietkiewicz ${ }^{\mathrm{b}}$ \\ a University of Warmia and Mazury in Olsztyn, Poland, e-mail: wojciech.kinski@uwm.edu.pl, \\ ORCID 0000-0003-4973-7604 \\ b University of Warmia and Mazury in Olsztyn, Poland, e-mail: papiet@uwm.edu.pl, \\ ORCID 0000-0002-6258-0384 \\ *Corresponding author: e-mail: wojciech.kinski@uwm.edu.pl
}

\begin{tabular}{|c|c|}
\hline ARTICLE INFO & ABSTRACT \\
\hline $\begin{array}{l}\text { Article history: } \\
\text { Received: August } 2020 \\
\text { Received in the revised form: } \\
\text { September } 2020 \\
\text { Accepted: September } 2020\end{array}$ & \multirow{2}{*}{$\begin{array}{l}\text { The article presents the results of tensile strength tests taking into ac- } \\
\text { count the influence of the printing nozzle diameter. The } 3 D \text { printing } \\
\text { method in FDM technology is described. The aim of the research was } \\
\text { to investigate the effect of the printing nozzle diameter installed in the } \\
\text { head. Samples printed with two types of filling were tested. The ob- } \\
\text { tained results were summarized and compared. The printing time of the } \\
\text { samples was compared with a diameter of each nozzle. Based on the } \\
\text { strength tests, it can be concluded that the tensile strength of the samples } \\
\text { made with the FDM printing technology is proportional to the used } \\
\text { printing nozzle diameter. }\end{array}$} \\
\hline $\begin{array}{l}\text { Key words: } \\
\text { 3D printing, } \\
\text { FDM, } \\
\text { 3D printing analysis, } \\
\text { strength tests }\end{array}$ & \\
\hline
\end{tabular}

\section{Introduction}

3D printers are increasingly used in low-volume production and production of prototypes. These are devices with which a user can create real objects based on a computer model. The incremental technology is based on building a model layer by layer, overlapping subsequent layers (Kiński and Pietkiewicz, 2018). Depending on the 3D printing technology, the building material may be light-curing resin, thermoplastics, polymer powders or metal alloys. The most common 3D printing technologies include:

- FDM (Fused Deposition Modeling),

- SLA (Stereolithography),

- SLS (Selective Laser Sintering).

FDM technology is the most common 3D printing technology taking into consideration the price of devices, consumables, and ease of use. It consists in production of a real object by applying the molten plastic layer on top of it, layer by layer, bonding the previously applied layers together (Nancharaiah et al., 2010). The material, in the form of a wire wound on a spool or granules, is delivered to the extruder where it is heated in the head to the appropriate plasticization temperature, where it is then extruded through a die (Bharath et al., 2014). Fig. 1 shows schematically how the FDM technology works. 


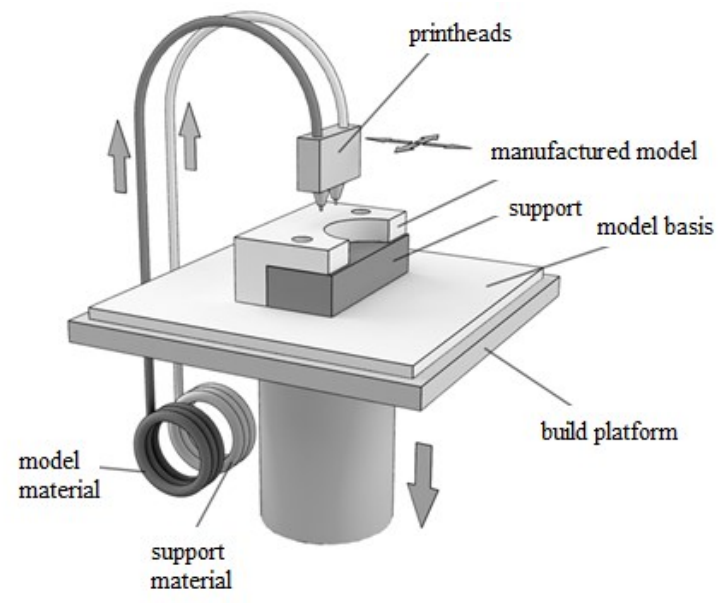

Figure 1. The principle of operation of the FDM method (Kiński and Pietkiewicz, 2016)

It is very important during the printing process to ensure a constant amount of embossed material. The following factors are affected:

- filament diameter and its tolerance,

- print head temperature,

- material extrusion speed.

This article presents the results of research on the influence of the printing nozzle diameter on the printing time and the tensile strength of the printed samples.

\section{Description of the conducted research}

The method of carrying out the tensile test of plastics is described in the PN-EN ISO 527:1998 standard, entitled Plastics. Determination of mechanical properties under static stretching. The three-dimensional model of the fitting was modeled using the SolidWorks program.

Below is an overview of the tearable sample (Fig. 2). Table 1 showsalldimensions:

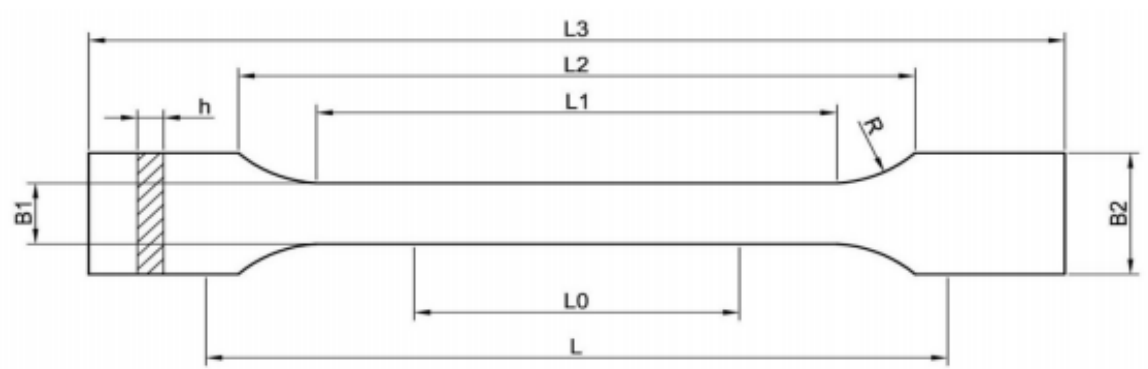

Figure 2. Sample intended for strength tests (Miazio, 2016) 
Influence of the printing...

Table 1.

Sample dimension (own elaboration)

\begin{tabular}{l|c}
\hline Sampledimension & Dimension \\
\hline L3 - totallength & $150 \mathrm{~mm}$ \\
L1 - length of the part delimited by lines & $40 \mathrm{~mm}$ \\
R - radius & $60 \mathrm{~mm}$ \\
L 2- distance between wide parallel parts & $106 \mathrm{~mm}$ \\
B2 - width at the ends & $20 \mathrm{~mm}$ \\
B1 - width of the narrow part & $10 \mathrm{~mm}$ \\
H - recommendedthickness & $4 \mathrm{~mm}$ \\
L0 - measuringlength & $50 \mathrm{~mm}$ \\
L - initial distance between the handles & $115 \mathrm{~mm}$ \\
\hline
\end{tabular}

The model with the above parameters was exported to a file in the STL format, which is one of the files required for reading by a 3D printer. The STL model is based on the construction of a model made of triangles (Bharath et al., 2014). Each surface is divided into a series of small triangles, and then each triangle vertex is described by 3 points representing their position relative to the coordinate axes (Zhengyanand Sanjay, 2015). The mapping of arcs and circular elements is simplified in some way (Maćkowiak et al., 2016). The threedimensional model of the strength sample prepared in this way was then converted into the GCODE language in external software, in which the user specifies, inter alia, printing temperature, speed, type and degree of filling or layer height. G-code is a standardized command language for controlling $\mathrm{CNC}$ devices. G-code commands can be written in three ways:

- manual entry in a text editor,

- code creation by a CAM type program,

- entering commands via the control panel.

In practice, only programs designed for that purpose are used to create G-code commands. The great advantage of these applications is that they only require device data and information on how the element is to be made, such as e.g. wall thickness or model filling.

The samples used for strength tests were printed from the biodegradable PLA (polylactic acid, polylactide) material, which is a polymer that is obtained from renewable natural raw materials such as e.g. corn meal (Nowak and Pająk, 2010). The temperature of the print head and the height of the sample layer for the individual nozzle diameters used are shown in Table 2 .

The printing temperature for the diameters of printing nozzles used in the test is different. It increases with diameter to ensure a uniform flow of the delivered material for printing. The model layer height is equal to half the printing diameter. For technical reasons, the wall thickness of the model corresponds to the diameter of the printing nozzle.

The breaking tests of strength samples were carried out on the Werkstoffprufmaschinen testing machine designed for stretching and compression. The accuracy of the sample breaking force reading was $\pm 0.025 \mathrm{kN}$. Due to the fact that the printed strength samples in the 
FDM technology are characterized by anisotropy and were produced with a different degree of internal filling, only the sample breaking force was measured.

Table 2.

Printing temperature of strength samples (own elaboration)

\begin{tabular}{lccc}
\hline $\begin{array}{c}\text { The diameter of the printing nozzle } \\
(\mathrm{mm})\end{array}$ & $\begin{array}{c}\text { Printheadtemperature } \\
\left({ }^{\circ} \mathrm{C}\right)\end{array}$ & $\begin{array}{c}\text { Printlayerheight } \\
(\mathrm{mm})\end{array}$ & $\begin{array}{c}\text { Wall thickness } \\
(\mathrm{mm})\end{array}$ \\
\hline 0.2 & 206 & 0.1 & 0.4 \\
0.3 & 208 & 0.15 & 0.6 \\
0.4 & 210 & 0.2 & 0.8 \\
0.5 & 212 & 0.25 & 1 \\
0.6 & 214 & 0.3 & 1.2 \\
0.8 & 218 & 0.4 & 1.6 \\
1 & 222 & 0.5 & 2 \\
\hline
\end{tabular}

Strength samples were printed in 3 to average the results of strength tests. Due to the course of the bursting force depending on the degree of filling, already known from the literature (Miazio, 2016), the test samples were printed with a filling degree of $50 \%$ and $100 \%$. The models were made with a cross-fill in the form of a mesh perpendicular to the model walls (at an angle of $90^{\circ}$ ). Table 3 shows the fixed parameters for printing samples.

Table 3.

Constant printing parameters (own study)

\begin{tabular}{l|c}
\hline Name & Value \\
Ambienttemperature & $20^{\circ} \mathrm{C}$ \\
The temperature of the build plate & $60^{\circ} \mathrm{C}$ \\
Printing speed & $50 \mathrm{~mm} \cdot \mathrm{s}^{-1}$ \\
\hline
\end{tabular}

The results obtained from the tensile tests are presented in Table 4. Each test was repeated three times.

Table 4.

Summary of average sample bursting forces

\begin{tabular}{l|c|c|c|c|c}
\hline \multicolumn{7}{c}{ Infill 50\% } \\
\hline $\begin{array}{l}\text { The diameter of the } \\
\text { printing nozzle } \\
(\mathrm{mm})\end{array}$ & $\begin{array}{c}\text { Layerhe- } \\
\text { ight } \\
(\mathrm{mm})\end{array}$ & $\begin{array}{c}\text { Test 1: the } \\
\text { breaking force } \\
(\mathrm{kN})\end{array}$ & $\begin{array}{c}\text { Test 2: the } \\
\text { breaking force } \\
(\mathrm{kN})\end{array}$ & $\begin{array}{c}\text { Test 3: the } \\
\text { breaking force } \\
(\mathrm{kN})\end{array}$ & $\begin{array}{c}\text { Average value of } \\
\text { the breaking force } \\
(\mathrm{kN})\end{array}$ \\
\hline 0.2 & 0.1 & 0.68 & 0.7 & 0.7 & 0.69 \\
\hline 0.3 & 0.15 & 0.72 & 0.75 & 0.75 & 0.74 \\
0.4 & 0.2 & 0.84 & 0.81 & 0.83 & 0.83
\end{tabular}


Influence of the printing...

\begin{tabular}{l|c|c|c|c|c}
0.5 & 0.25 & 1.1 & 1.15 & 1.14 & 1.13 \\
0.6 & 0.3 & 1.12 & 1.12 & 1.15 & 1.13 \\
0.8 & 0.4 & 1.18 & 1.15 & 1.17 & 1.17 \\
\hline 1 & 0.5 & 1.18 & 1.25 & 1.21 & 1.21 \\
\hline
\end{tabular}

\begin{tabular}{l|c|c|c|c|c}
\hline $\begin{array}{l}\text { The diameter of the } \\
\text { printing nozzle } \\
(\mathrm{mm})\end{array}$ & $\begin{array}{c}\text { Layerhe- } \\
\text { ight } \\
(\mathrm{mm})\end{array}$ & $\begin{array}{c}\text { Test 1: the } \\
\text { breaking force } \\
(\mathrm{kN})\end{array}$ & $\begin{array}{c}\text { Test 2: the } \\
\text { breaking force } \\
(\mathrm{kN})\end{array}$ & $\begin{array}{c}\text { Test 3: the } \\
\text { breaking force } \\
(\mathrm{kN})\end{array}$ & $\begin{array}{c}\text { Average value of } \\
\text { the breaking force } \\
(\mathrm{kN})\end{array}$ \\
\hline 0.2 & 0.1 & 1.88 & 1.9 & 1.9 & 1.89 \\
\hline 0.3 & 0.15 & 1.89 & 1.91 & 1.9 & 1.90 \\
0.4 & 0.2 & 1.9 & 1.92 & 1.9 & 1.91 \\
0.5 & 0.25 & 1.95 & 1.9 & 1.94 & 1.93 \\
0.6 & 0.3 & 1.85 & 1.85 & 1.82 & 1.84 \\
0.8 & 0.4 & 1.69 & 1.7 & 1.67 & 1.69 \\
\hline 1 & 0.5 & 1.5 & 1.47 & 1.5 & 1.49 \\
\hline
\end{tabular}

In Fig. 3. a graphic interpretation of the results is shown.

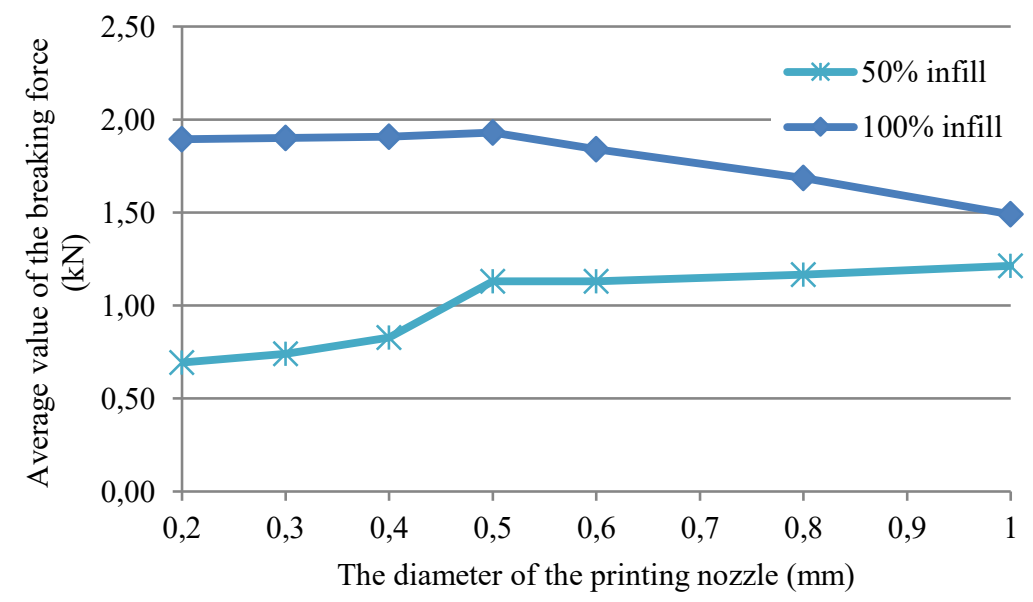

Figure3. Average sample breaking force (own elaboration)

Table 5 presents the test results concerning the printing time of individual samples depending on the diameter of the printing nozzle. 
Table 5.

Duration of printing strength samples

\begin{tabular}{|c|c|}
\hline \multicolumn{2}{|c|}{$50 \%$ infill } \\
\hline The diameter of the printing nozzle $(\mathrm{mm})$ & Printing time (min) \\
\hline 0.2 & 119 \\
\hline 0.3 & 61 \\
\hline 0.4 & 39 \\
\hline 0.5 & 27 \\
\hline 0.6 & 21 \\
\hline 0.8 & 15 \\
\hline 1 & 11 \\
\hline \multicolumn{2}{|c|}{$100 \%$ infill } \\
\hline Layerheight (mm) & Printing time (min) \\
\hline 0.2 & 192 \\
\hline 0.3 & 90 \\
\hline 0.4 & 53 \\
\hline 0.5 & 35 \\
\hline 0.6 & 25 \\
\hline 0.8 & 17 \\
\hline 1 & 12 \\
\hline
\end{tabular}

The graph in Fig. 3 is a graphic interpretation of the dependence of the average sample bursting force on the diameter of the printing nozzle used and its degree of filling. The dependence of the printing time due to the diameter of the printing nozzle is shown in Fig. 4.

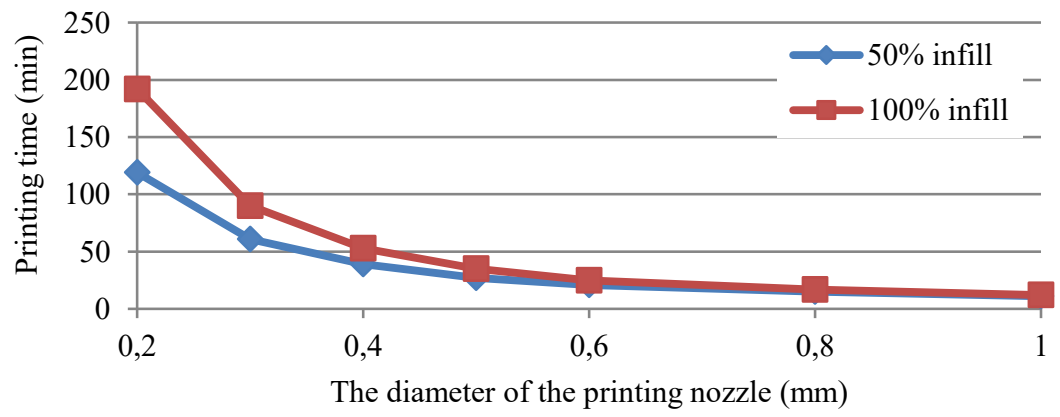

Figure 4. Time dependence on the height of the model layer (own elaboration) 
Influence of the printing...

The view of a sample after the strength test is shown in Fig. 5. Fig. 6 shows a comparison of the resolution of samples printed with different diameters of printing nozzles $(0.2$ and $1 \mathrm{~mm})$.

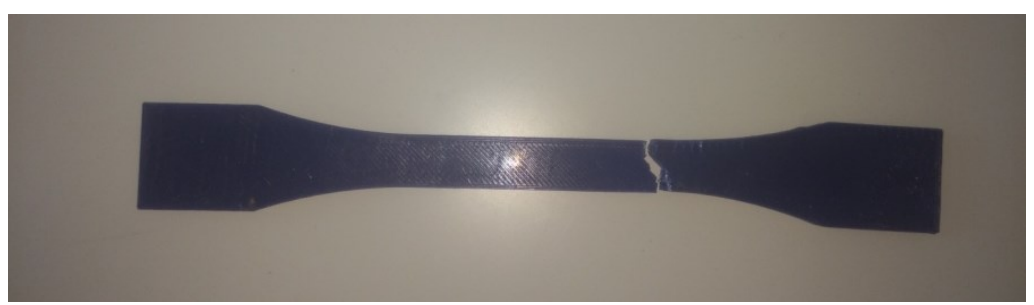

Figure5. Example of a sample after strength test (own elaboration)

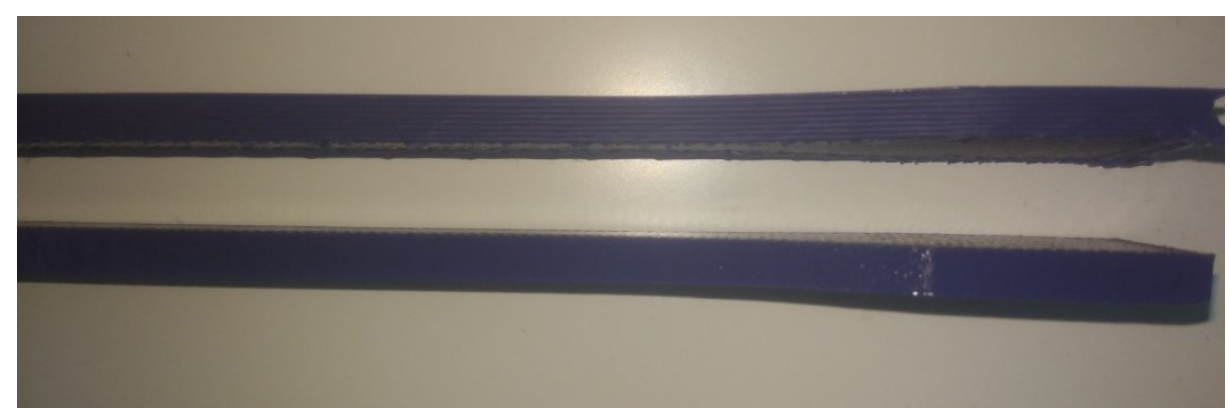

Figure 6. The height of the layers of strength samples with the use of nozzles with a diameter of $0.2 \mathrm{~mm}$ and $1 \mathrm{~mm}$ (own elaboration)

\section{Summary}

Models produced with the use of additive techniques, due to their anisotropy, have a different strength than objects produced with the traditional injection method. However, with the use of software that prepares a 3D model for printing and innovative devices, it is possible to significantly affect the strength parameters by selecting the appropriate parameters (e.g. type and density of filling, model orientation on the working platform).

After the strength tests performed, it can be seen that the tested samples broke in the middle of the sample length. In the case of strength samples with a filling degree of $50 \%$, the sample breaking force increases with the increase of the printing nozzle diameter. On the other hand, in samples with the filling degree equal to $100 \%$, the bursting force decreases with the increase of the printing nozzle diameter. The use of a nozzle with a diameter of $0.5 \mathrm{~mm}$ translates into a printout of samples characterized by high strength and good-quality external appearance of the manufactured object. On the other hand, the printing time decreases with increasing the used printing nozzle. After printing the samples, it can be noticed that as the diameter of the printing nozzle increases, the printed sample is visually imaged in 
a worse degree than the samples printed with a smaller diameter nozzle. This is due to the width of the embossed path.

The strength of printed elements is influenced by a number of different factors such as: type of material used, printing speed, printing temperature, type of model filling, cooling of the printed model during printing, as well as the printing nozzle diameter. At the Department of Mechanics and Fundamentals of Machine Design, UWM in Olsztyn, research is carried out on their influence on the strength of models.

\section{References}

Bharath, V., Dharma, R., Prakash, N., Henderson, M. (2014).Sensitivity Of Rp Surface Finish To Process Parameter Variation. Journal of North America, 3, 124-133.

Kiński, W., Pietkiewicz, P. (2016). Parametry eksploatacyjne wpływające na jakość wydruków w technologii FDM. Mechanik, 7, 632-636.

Kiński, W., Pietkiewicz, P. (2018). Koncepcja systemu podawania materiału w drukarkach 3D wykorzystującego zużyty materiał w technologii FDM. Mechanik, 7, 543-545.

Maćkowiak, P., Magdziarz, D., Kotyk, M., Tomkiewic,z R., Kabat, P. (2016). Wielkość i liczba wad w elementach wyprodukowanych metodą FDM w zależności od parametru prędkości wytwarzania. Postepy w Inżynierii Mechanicznej, 7, 17-31.

Miazo, Ł. (2016). Badanie wytrzymałości na rozciąganie próbek wydrukowanych w technologii FDM z różną gęstością wypełnienia. Mechanik,7, 533-538.

Nancharaiah, T., Raju, D.R., Raju, V.R. (2010). An experimental investigation on surface quality and dimensional accuracy of FDM components. International Journal on Emerging Technologies, 1, 106-111.

Nowak, B., Pająk, J. (2010). Biodegradacja polilaktydu (PLA).Archiwum Gospodarki Odpadami i Ochrony Srodowiska, 2, 1-10.

Zhengyan, Z.,Sanjay, J. (2015). An improved slicing algorithm with efficient contour construction using STL files. The International Journal of Advanced Manufacturing Technology, 80, $1347-1362$.

\section{WPEYW ŚREDNICY DYSZY DRUKUJĄCEJNA WYTRZYMALOŚĆ NA ROZCIĄGANIE WYTWARZANYCH MODELI 3D W TECHNOLOGII FDM}

Streszczenie. W artykule przedstawiono wyniki badań wytrzymałościowych na rozciąganie z uwzględnieniem wpływu średnicy dyszy drukującej. Opisano metodę druku 3D w technologii FDM. Celem badań było zbadanie wpływu średnicy dyszy drukującej zainstalowanej w głowicy. Wykonano badania próbek wydrukowanych przy dwóch rodzajach wypełnienia. Otrzymane wyniki zostały zestawione i porównane. Porównany został czas wydruku próbek poszczególną średnicą dyszy. Na podstawie prób wytrzymałościowych można stwierdzić, że wytrzymałość na rozciąganie próbek wykonanych w technologii druku FDM jest proporcjonalna do zastosowanej średnicy dyszy drukującej.

Słowa kluczowe: druk 3D, FDM, analiza druku 3D, badania wytrzymałościowe 